\title{
EVALUATION OF OPEN-POLLINATED AND HYBRID MAIZE VARIETIES IN THE SPRING SEASON AT BAITADI DISTRICT, NEPAL
}

\author{
K. Bista", R. Gaire and K. Devkota \\ Faculty of agriculture \\ Agriculture and Forestry University, Rampur, Chitwan, Nepal
}

\begin{abstract}
Being a maize producing region, cultivation of hybrid and improved maize varieties in the spring season is very low in Baitadi district. In order to examine the performances of different maize varieties, five maize varieties including both open-pollinated (i.e. Arun-2, Arun-4 and Rampur composite) and hybrid varieties (i.e. Rajkumar and Rampur Hybrid-10) were tested using Randomized Complete Block Design (RCBD) in spring season during February to August, 2020 at Dasarathch and municipality-1, Baitadi. The highest days to emergence of seedlings was in Rampur Hybrid-10 (30 days) and the lowest days to emergence was in Arun-2 (23 days) and Arun-4 (23 days), respectively. The plant height was significantly higher in Rajkumar $(156.4 \mathrm{~cm})$, whereas the leaf area index were significantly higher in Arun-2 $(4.36 \mathrm{~cm})$. Similarly, the phenological behavior like days to $50 \%$ tasseling (112 days) and silking (119 days) were significantly earlier in Arun-4. Likewise, yield attributing characteristics like cob length, cob diameter, number of rows/cobs, number of kernels/rows, shelling\%, thousand grain weight (TGW) were found significantly higher in hybrid maize varieties as compared to openpollinated varieties. Grain yield was found significantly higher in hybrids Rajkumar recording yield of $5.32 \mathrm{Mt} \mathrm{ha}^{-1}$ closely followed by Rampur Hybrid-10 (4.75 Mt ha ${ }^{-1}$ ) whereas open-pollinated Rampur composite, Arun-2 and Arun-4 recorded grain yield of $4.58 \mathrm{Mt} \mathrm{ha}^{-1}, 3.99 \mathrm{Mt} \mathrm{ha}^{-1}$ and $2.33 \mathrm{Mt} \mathrm{ha}^{-1}$ respectively. The results indicated that hybrid varieties were promising and should be promoted for general cultivation in the hills area of Nepal.
\end{abstract}

Keywords: Performance, Far-western hills, Variety, Grain yield

\footnotetext{
*Corresponding author: bistakaushila02@gmail.com
} 


\section{INTRODUCTION}

Maize (Zea mays L.) is one of the most important staple crop in the world. Globally it is a widely grown cereals which contribute to food security in most of the developing countries. In Nepal, it is considered as the second most important crop in terms of area and production (Karki et al., 2015). The cereal crops contribute about $49.41 \%$ to Agriculture Gross Domestic Product (AGDP), whereas, maize alone contributes $6.66 \%$ to AGD (MOALD, 2017). It is cultivated in 957,650 ha of land with total production of 2,835,674 Mt and productivity of $2.96 \mathrm{Mt} \mathrm{ha}^{-1}$ (AICC, 2021). Out of the total maize area, Terai occupies $18.95 \%$, mid-hills $72.28 \%$ and high-hills $8.76 \%$ (MOALD, 2017). Further, improved maize seed covers 850,420 ha of land with the total production of $2,231,425 \mathrm{Mt}$ and yield of $2.624 \mathrm{Mt} \mathrm{ha}^{-1}$ in contrast to the total land coverage of 900,288 ha with the total production of 2,300,121 Mt and the yield of $2.555 \mathrm{Mt} \mathrm{ha}^{-1}$ (MOALD, 2017).

In hills, maize is the principle food crop where maize grain are used as food, feed and seed, and stover is used as animal fodder (Lamichhane et al., 2015). In the hills area, maize is cultivated only in rainy season results in lagging behind the national productivity. The technologies developed based on maize and recommended for the farmers to date are not fully adopted (Kc et al., 2015). Nearly half the area under maize is planted with traditional varieties i.e., home saved seeds, which are continuously at the risk of degenerating due to open pollination of the maize (Ghimire et al., 2016). Due to unavailability of high yielding genotypes of maize suitable to agro-climatic condition of Far-western development region (Prasai et al., 2015), farmers are reluctant to use improved seed varieties and most of them use local varieties without the replacement of seed for many years. The use of highquality improved seeds increases the crop yield by 20-30\% (SQCC, 2013). But farmers in Nepal still rely on local cultivars with low seed replacement rate of maize in Nepal about $11.3 \%$ (Pokhrel, 2013). Only some farmer access to the extension worker and timely availability of seeds adopts the improved varieties and remaining majority portion of farmers have been growing local cultivars (Pandey et al., 2019).

Baitadi district lies in hills of Nepal with suitable climate for growing maize. Maize is cultivated in the area 5786 ha with the total production of $10414 \mathrm{Mt}$ and yield of 1.8 $\mathrm{Mt} \mathrm{ha}^{-1}$ in the year 2018/19 while the productivity of the improved maize varieties is $2.4 \mathrm{Mt} \mathrm{ha}^{-1}$ and that of local varieties is $1.51 \mathrm{Mt} \mathrm{ha}^{-1}$ (PMAMP, 2019). PMAMP maize zone, Baitadi is focusing to commercialized, self-reliant and increase the maize production area with high price to the farmers to uplift their livelihood (PMAMP, 2019). But still there is no cultivation of maize in all the season. Therefore, this study was conducted in Baitadi in order to know about the 
performance and adoption of the high yielding hybrid and improved varieties in the spring season and further to increase the preferences of farmers to cultivate maize in spring season.

\section{MATERIALS AND METHODS}

\section{Experimental site}

This study was conducted in Dasarathch and municipality-1, Baitadi in spring season during February to August, 2020. This location is subtropical zone of Nepal with three distinct seasons namely: rainy monsoon (June-October), cool winter (November-February), and mild spring (March-May). The weather data during study period are presented in Fig. 1.

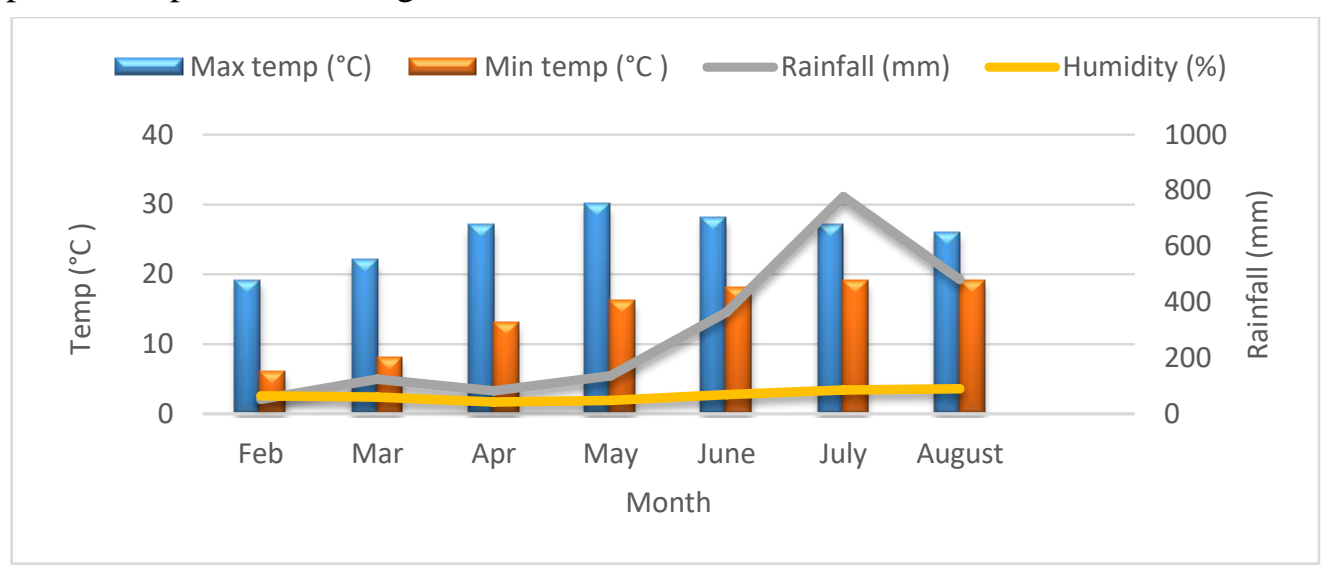

Figure 1. Weather data during the growing period of maize at Baitadi, Nepal, 2020

\section{Experimental details}

The experiment was carried out in randomized complete block design (RCBD) with four replications and five treatments. The treatments consisted of five different maize varieties i.e., Arun-2, Arun-4, Rampur composite (open-pollinated), Rajkumar and Rampur Hybrid-10 (hybrid). Individual plot size was $4.2 \mathrm{~m} \times 2 \mathrm{~m}$ and seeds were sown at spacing of $60 \mathrm{~cm} \times 25 \mathrm{~cm}$ and all plots were fertilized with 120:60:40 kg NPK/ha full dose of di-ammonium phosphate (DAP) and murate of potash (MOP) at basal dose and 3 equal split doses of nitrogen i.e., at the time of sowing, at knee high stage and tasseling stage. 
Table 1. Information regarding maize varieties under study

\begin{tabular}{|c|c|c|c|c|c|c|c|c|c|}
\hline $\begin{array}{l}\text { Maize } \\
\text { Variety }\end{array}$ & $\begin{array}{l}\text { Released } \\
\text { Year }\end{array}$ & . & Parentage & $\begin{array}{l}\text { Plant } \\
\text { Height } \\
(\mathrm{cm})\end{array}$ & $\begin{array}{l}\text { Maturity } \\
\text { days }\end{array}$ & $\begin{array}{c}\text { Yield } \\
\text { Potential } \\
\left(\mathrm{Mt} \mathrm{ha}^{-1}\right)\end{array}$ & $\begin{array}{l}\text { Recommended } \\
\text { areas }\end{array}$ & $\begin{array}{c}\text { Varietal } \\
\text { characteristic }\end{array}$ & $\begin{array}{l}\frac{\vdots}{0} \\
0 \\
\frac{8}{0} \\
\tilde{n}\end{array}$ \\
\hline Arun- 2 & $\begin{array}{l}1982(203 \\
9 \text { B.S })\end{array}$ & $\sum_{\substack{\infty \\
e}}^{\infty}$ & $\begin{array}{l}\text { UNCAC- } \\
242 * \text { Philippi } \\
\text { nes DMR }\end{array}$ & $140-200$ & $80-90$ & 3.0 & $\begin{array}{l}\text { Terai, Inner Terai } \\
\text { and lower hills }\end{array}$ & $\begin{array}{l}\text { Dwarf plant } \\
\text { height, non- } \\
\text { lodging, reddish } \\
\text { color of shelled } \\
\text { cob }\end{array}$ & 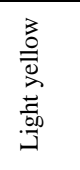 \\
\hline Arun-4 & $\begin{array}{l}2015(207 \\
2 \text { B.S.) }\end{array}$ & $\begin{array}{l}\overline{\tilde{0}} \\
\text { zे }\end{array}$ & $\begin{array}{l}\text { Formed using } \\
\text { elite } \\
\text { introduced } \\
\text { germplasm } \\
\text { and local } \\
\text { landraces }\end{array}$ & $143-247$ & 113-115 & 4.2 & $\begin{array}{l}\text { Mid-western to } \\
\text { Eastern Terai, inner } \\
\text { Terai and mid-hills; } \\
\text { winter and spring } \\
\text { season in Terai and } \\
\text { inner Terai, and } \\
\text { summer season in } \\
\text { mid-hills }\end{array}$ & $\begin{array}{l}\text { Kernel flint type, } \\
\text { short plant height } \\
\text { and internodes } \\
\text { green not swollen. }\end{array}$ & $\frac{3}{0}$ \\
\hline $\begin{array}{l}\text { Rampur } \\
\text { Composite }\end{array}$ & $\begin{array}{l}1975(203 \\
2 \text { B.S.) }\end{array}$ & 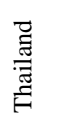 & $\begin{array}{l}\text { Thai } \\
\text { Composite- } \\
1 \text { *Suwan-1 }\end{array}$ & $210-220$ & $115-130$ & 4.42 & $\begin{array}{l}\text { Terai, inner Terai } \\
\text { and lower hill }\end{array}$ & $\begin{array}{l}\text { Tolerance to } \\
\text { Downy mildew, } \\
\text { tight husk cover }\end{array}$ & 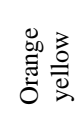 \\
\hline
\end{tabular}

\section{Data recording, measurements and analysis}

The observations on emergence, plant height, Leaf Area Index (LAI), days to 50\% tasseling, days to 50\% silking and yield was taken. Five representative plants from each plot were randomly selected for the observation and measured with the help of measuring tape. LAI is defined as the green leaf area per unit ground surface area $\left(\mathrm{LAI}=\right.$ leaf area $/$ ground area, $\left.\mathrm{m}^{2} / \mathrm{m}^{2}\right)$. According to Montgomery $(1911)$, the general equation to estimate the individual leaf area of maize as

Leaf Area $(\mathrm{LA})=\mathrm{A} * \mathrm{~L} * \mathrm{~W}$, where $\mathrm{A}=$ Leaf Shape Coefficient, $\mathrm{L}=$ Length and $\mathrm{W}=$ Width. The coefficient was conventionally assumed 0.75 for maize leaf.

For the measurement of yield and yield attributing character, three rows were selected from each plot and from those five representative cobs were taken for the observations of cob length, cob diameter, kernel rows/cob, kernels/cob, test weight and grain yield, dried (around 15\% moisture) and shelled (80\% shelling). Data regarding thousand grains weight were recorded by counting randomly selected 1000 grains from each sub plot and weighed with electronic balance. The shelling percentage was calculated as (Biru, 1976):

$$
\text { Shelling percentage }=\frac{\text { Grain y ield }(\mathrm{kg})}{\text { Cob y ield }(\mathrm{kg})} \times 100
$$

Whereas, grain yield was calculated on hectare basis by using following formulae (Biru, 1976): 


$$
\text { Grain yield }\left(\mathrm{Mt} \mathrm{ha}^{-1}\right)=\frac{\text { FEW } \times \mathrm{SP} \times(100-\mathrm{GC})}{\mathrm{NHA} \times 85 \times 10}
$$

Where,

$$
\text { FEW }=\text { Filled Ears Weight }(\mathrm{Kg}) \quad \mathrm{SP}=\text { Shelling percentage }(\%)
$$

$\mathrm{GC}=$ grain moisture content at harvest $(\%) \mathrm{NHA}=$ net harvested area $\left(\mathrm{m}^{2}\right)$

Data were first tabulated in Microsoft Excel (MS- Excel), then Analysis of variance (ANOVA) for all data was computed using R-studio computer software package. All the analyzed data were subjected to Duncan's Multiple Range Test (DMRT) for mean comparison at $5 \%$ level of significance.

\section{RESULTS AND DISCUSSION}

\section{Varietal effect on emergence}

The emergence of different maize varieties was significant $(p<0.05)$. It was recorded that the highest days to emergence was found in Rampur Hybrid-10 (30 days) and little earlier in Arun-2 (23 days), Arun-4 (23 days), Rajkumar (24 days) and Rampur composite (26 days) respectively (Table 2 ).

Table 2. Days to emergence @ 80\% of different maize varieties under Spring Season at Baitadi, 2020

\begin{tabular}{ll}
\hline Treatments & Days to emergence @ 80\% \\
\hline Arun-2 & $23^{\mathrm{a}}$ \\
Arun-4 & $23^{\mathrm{a}}$ \\
Rampur composite & $26^{\mathrm{a}}$ \\
Rajkumar & $24^{\mathrm{a}}$ \\
Rampur Hybrid-10 & $30^{\mathrm{b}}$ \\
\hline LSD $(0.05)$ & 4.38 \\
SEm $( \pm)$ & 1.41 \\
CV\% & 11.45 \\
P-value & $0.014^{*}$ \\
\hline Grand Mean & 24.8 \\
\hline
\end{tabular}

Note: The common letter (s) within the column indicate non-significant difference based on Duncan Multiple Range Test (DMRT)

According to (JICA, 2016), a range of $21-27^{\circ} \mathrm{C}$ temperature is suitable for the better growth of maize plant while $20^{\circ} \mathrm{C}$ is required for germination but during the maize seed sown period i.e., February, the maximum temperature was $18^{\circ} \mathrm{C}$ and minimum was $5^{\circ} \mathrm{C}$ which was lower than the required and after sowing there was heavy rainfall 
with hailstorm that hinders the emergence as well as growth of maize. It has been reported that there are negative effects of low temperature on germination; germination being nil below $10^{\circ} \mathrm{C}$ (Wijewardana et al., 2016). In addition, once the seed begins to germinate, a significant change in soil temperature can cause problems for mesocotyl growth (Elmore, 2012).

\section{Varietal effect on Biometrical observations}

\section{Plant height}

Plant height was found non-significant at 30 Days after sowing (DAS) whereas it was significantly influenced by maize varieties at 60,90, 120 DAS. It was significantly higher in Rajkumar $(66.4 \mathrm{~cm})$ and Arun-2 $(65.15 \mathrm{~cm})$ at 60 DAS and at 90 DAS $(93.88 \mathrm{~cm})$ and 120 DAS $(154.6 \mathrm{~cm})$, it was significantly higher in Rajkumar respectively (Table 3 ).

Table 3. Plant height of maize of different maize varieties during spring at Baitadi, 2020

\begin{tabular}{lllll}
\hline \multirow{2}{*}{ Treatments } & \multicolumn{4}{c}{ Plant height $(\mathrm{cm})$} \\
\cline { 2 - 5 } & \multicolumn{1}{c}{$30 \mathrm{DAS}$} & \multicolumn{1}{c}{ 60DAS } & \multicolumn{1}{c}{$90 \mathrm{DAS}$} & $120 \mathrm{DAS}$ \\
\hline Arun-2 & 10.31 & $58.58^{\mathrm{ab}}$ & $84.48^{\mathrm{ab}}$ & $132.0^{\mathrm{ab}}$ \\
Arun-4 & 9.84 & $65.15^{\mathrm{a}}$ & $84.78^{\mathrm{ab}}$ & $111.1^{\mathrm{bc}}$ \\
Rampur composite & 10.51 & $41.28^{\mathrm{bc}}$ & $67.85^{\mathrm{bc}}$ & $104.4^{\mathrm{bc}}$ \\
Rajkumar & 10.05 & $66.4^{\mathrm{a}}$ & $93.88^{\mathrm{a}}$ & $154.6^{\mathrm{a}}$ \\
Rampur hybrid-10 & 8.69 & $25^{\mathrm{c}}$ & $62.86^{\mathrm{c}}$ & $88.0^{\mathrm{c}}$ \\
\hline LSD (0.05) & Ns & 18.42 & 17.05 & 26.74 \\
SEm ( \pm$)$ & 0.29 & 7.95 & 5.79 & 11.55 \\
CV\% & 12.97 & 23.32 & 14.05 & 15.01 \\
P-value & 0.32 & $0.002^{* *}$ & $0.0097^{* *}$ & $0.0017^{* *}$ \\
\hline Grand Mean & 9.88 & 51.28 & 78.77 & 118.02 \\
\hline
\end{tabular}

Note: The common letter(s) within the column indicate non-significant difference based on Duncan Multiple Range Test (DMRT)

Difference of plant height was found in different varieties. This was due to the fact that the plant height is a genetically as well as environmentally controlled factor so the height of different varieties remain different (Kunwar and Shrestha, 2014). Not only genetic factor, environmentally the plant height of maize was influenced and it could not be neglected. The reason behind decrease in plant height due to environmental factors are as a result of low soil moisture and low soil temperature during growing period. The environmental stress at vegetative growth stage reduced vegetative traits slightly (Sabiel et al., 2014). Under heat and drought stress condition during spring season may be the reason for lower plant height thus reduce the 
transpiration and therefore reduce the demand for moisture during drought stress at growth (Zhang et al., 2016). Also, the temperatures encountered with early planting tend to reduce plant height mainly by decreasing internode length and less so by reducing leaf numbers (Swanson and Wilhelm, 1996).

\section{Leaf Area Index (LAI)}

The LAI at 30 DAS was non-significant but significant at 60, 90 and 120 DAS as influenced by different varieties. At 60 DAS (0.24) and 120 DAS (4.36), LAI was significantly higher in Arun-2. However, at 90 DAS the LAI was significantly higher in both Arun-2 (3.13) and Rajkumar (3.02) (Table 4).

Table 4. Leaf Area Index (LAI) of different maize varieties during spring at Baitadi, 2020

\begin{tabular}{lllll}
\hline \multirow{2}{*}{ Treatments } & \multicolumn{4}{c}{ Leaf Area Index (LAI) } \\
\cline { 2 - 5 } & \multicolumn{1}{c}{ 30DAS } & \multicolumn{1}{c}{$60 \mathrm{DAS}$} & \multicolumn{1}{c}{ 90DAS } & \multicolumn{1}{c}{$120 \mathrm{DAS}$} \\
\hline Arun-2 & 0.013 & $0.239^{\mathrm{a}}$ & $3.134^{\mathrm{a}}$ & $4.355^{\mathrm{a}}$ \\
Arun-4 & 0.012 & $0.164^{\mathrm{bc}}$ & $1.827^{\mathrm{bc}}$ & $2.668^{\mathrm{c}}$ \\
Rampur composite & 0.016 & $0.181^{\mathrm{bc}}$ & $2.431^{\mathrm{ab}}$ & $3.295^{\mathrm{bc}}$ \\
Rajkumar & 0.014 & $0.218^{\mathrm{ab}}$ & $3.015^{\mathrm{a}}$ & $3.99^{\mathrm{ab}}$ \\
Rampur Hybrid-10 & 0.010 & $0.146^{\mathrm{c}}$ & $1.355^{\mathrm{c}}$ & $2.443^{\mathrm{c}}$ \\
\hline LSD $(0.05)$ & $\mathrm{Ns}$ & 0.05 & 0.79 & 2.18 \\
SEm $( \pm)$ & 0.001 & 0.017 & 0.34 & 0.368 \\
CV\% & 22.62 & 18.13 & 21.89 & 17.07 \\
P-value & 0.098 & $0.014^{*}$ & $0.0015^{* *}$ & $0.0019^{* *}$ \\
\hline Grand Mean & 0.013 & 0.190 & 2.35 & 3.35 \\
\hline
\end{tabular}

Note: The common letter(s) within the column indicate non-significant difference based on Duncan Multiple Range Test (DMRT)

Recently developed maize hybrids (Rampur Hybrid-10) have upright leaves allowing lighter to penetrate the leaf canopy and thus lower leaf area (Lambert et al., 2014). Initial slow growth of maize seedling was probably due to lower early spring temperature (Amgain, 2011).

\section{Varietal effect on Phenological observation}

Flowering is an important factor contributing to grain formation in maize. Phenology was found significant $(p<0.001)$ to different maize varieties (Table 5). The anthesissilking interval (ASI) DAS as comparatively shorter period in Rajkumar (4.5 days) and longer period in Arun-4 (7.5 days). Delayed emergence due to cold, wet conditions lengthens the duration of maize. The duration to reach tasseling and silking in spring maize was longer than that in summer maize because spring maize 
had a slower early growth as it was staggered with the low initial temperature until mid-April (Khanal et al., 2019).

Table 5. Crop phenology of different maize varieties during spring at Baitadi, 2020

\begin{tabular}{llll}
\hline \multirow{2}{*}{ Treatments } & \multicolumn{3}{c}{ Phenology } \\
\cline { 2 - 4 } & \multicolumn{1}{c}{ Days to 50\% tasseling } & Day to 50\% Silking & \multicolumn{1}{c}{ ASI } \\
\hline Arun-2 & $114^{\mathrm{b}}$ & $120^{\mathrm{ab}}$ & $6.25^{\mathrm{c}}$ \\
Arun-4 & $112^{\mathrm{a}}$ & $119^{\mathrm{a}}$ & $7.5^{\mathrm{d}}$ \\
Rampur Composite & $121^{\mathrm{d}}$ & $126^{\mathrm{c}}$ & $5.75^{\mathrm{bc}}$ \\
Rajkumar & $117^{\mathrm{c}}$ & $122^{\mathrm{b}}$ & $4.5^{\mathrm{a}}$ \\
Rampur Hybrid-10 & $128^{\mathrm{e}}$ & $133^{\mathrm{d}}$ & $5.25^{\mathrm{ab}}$ \\
\hline LSD $(0.05)$ & 2.17 & 2.23 & 0.90 \\
SEm $( \pm)$ & 2.87 & 2.61 & 0.50 \\
CV, $\%$ & 1.19 & 1.17 & 9.99 \\
P-value & $<0.001 * * *$ & $<0.001 * * *$ & $<0.001^{* * *}$ \\
\hline Grand Mean & 118.2 & 124.05 & 5.85 \\
\hline
\end{tabular}

Note: The common letter(s) within the column indicate non-significant difference based on Duncan Multiple Range Test (DMRT)

\section{Varietal effects on yield and yield attributes}

Table 6. Yield attributing character of different maize varieties at Baitadi, 2020

\begin{tabular}{llllll}
\hline \multicolumn{1}{c}{ Treatments } & $\begin{array}{c}\text { No. of cob } \\
\text { plant }^{-1} \\
(\text { No. })\end{array}$ & $\begin{array}{c}\text { Cob } \\
\text { Length } \\
(\mathrm{cm})\end{array}$ & $\begin{array}{c}\text { Cob } \\
\text { Diameter } \\
(\mathrm{cm})\end{array}$ & $\begin{array}{c}\text { No. of } \\
{\text { row } \mathrm{cob}^{-1}}^{-1}\end{array}$ & $\begin{array}{c}\text { No. of } \\
\text { Kernel }^{-1} \\
\text { row }^{-1}\end{array}$ \\
\hline Arun-2 & $1.02^{\mathrm{b}}$ & $14.75^{\mathrm{ab}}$ & $4.37^{\mathrm{ab}}$ & $13.7^{\mathrm{a}}$ & $21.45^{\mathrm{b}}$ \\
Arun-4 & $1.00^{\mathrm{b}}$ & $13.35^{\mathrm{b}}$ & $3.42^{\mathrm{c}}$ & $12.4^{\mathrm{bc}}$ & $18.20^{\mathrm{c}}$ \\
Rampur composite & $1.15^{\mathrm{b}}$ & $14.59^{\mathrm{ab}}$ & $4.31^{\mathrm{b}}$ & $11.6^{\mathrm{c}}$ & $20.45^{\mathrm{bc}}$ \\
Rajkumar & $1.10^{\mathrm{b}}$ & $15.86^{\mathrm{a}}$ & $4.59^{\mathrm{a}}$ & $14.1^{\mathrm{a}}$ & $24.65^{\mathrm{a}}$ \\
Rampur Hybrid-10 & $1.92^{\mathrm{a}}$ & $14.42^{\mathrm{b}}$ & $4.45^{\mathrm{ab}}$ & $12.9^{\mathrm{ab}}$ & $22.90^{\mathrm{ab}}$ \\
\hline LSD $(0.05)$ & 0.16 & 1.33 & 0.23 & 1.23 & 2.50 \\
SEm $( \pm)$ & 0.17 & 0.40 & 0.21 & 0.45 & 1.09 \\
CV, \% & 8.51 & 5.91 & 3.52 & 6.16 & 7.55 \\
P-value & $<0.001^{* * *}$ & $0.02^{*}$ & $<0.001^{* * *}$ & $0.006^{* *}$ & $0.001^{* *}$ \\
\hline Grand Mean & 1.24 & 14.59 & 4.23 & 12.94 & 21.53 \\
\hline
\end{tabular}

Note: The common letter(s) within the column indicate non-significant difference based on Duncan Multiple Range Test (DMRT) 


\section{Number of cobsplants ${ }^{-1}$}

The numbers of cobs/plant of different maize varieties are presented in Table 6 and was very highly significant $(\mathrm{p}<0.001)$. The highest no of cob was found in Rampur Hybrid-10 (1.92) which is almost double than other varieties but most of them were sterile. Some researchers have shown that higher number of cobs is obtained in hybrid maize (Khanal et al., 2019).

\section{Cob length}

Cob length of different maize varieties were significant $(p<0.05)$ (Table 6). Cob length was significantly higher in Rajkumar $(15.86 \mathrm{~cm})$ which was at par with Rampur Composite $(14.59 \mathrm{~cm})$ and Arun-2 $(14.75 \mathrm{~cm})$. Arun-4 $(13.35 \mathrm{~cm})$ and Rampur Hybrid-10 (14.42 cm) showed the lowest cob length.

\section{Cob diameter}

Cob diameter of different maize varieties is presented in Table 6 and was highly significant $(\mathrm{p}<0.001)$. The highest cob diameter was observed in Rajkumar $(4.59 \mathrm{~cm})$ which was at par with Rampur Hybrid-10 $(4.45 \mathrm{~cm})$ and Arun-2 $(4.37 \mathrm{~cm})$ while lowest diameter was in Arun-4 $(3.42 \mathrm{~cm})$.

\section{Number of grain rowscob ${ }^{-1}$}

The numbers of grain rows/cob of different maize varieties are presented in Table 6 and was significant $(\mathrm{p}<0.01)$ with varieties. The highest grain row per cob were obtained in Rajkumar (14.1) and Arun-2 (13.7) which at par with Rampur Hybrid-10 (12.9) and the lowest grain rows per cob (11.6) which at par with Arun-4 (12.4) were obtained.

\section{Number of kernels grain row ${ }^{-1}$}

The number of kernels/grain row of different maize varieties are presented in Table 6 and was significant $(\mathrm{p}<0.01)$. The number of kernels per row was highest in Rajkumar (24.65) which at par with Rampur Hybrid-10 (22.9) and the lowest kernels/row was in Arun-4 (18.2) which was at par with Rampur composite (20.45).

\section{Sterility percentage}

The sterility percentage of different maize varieties which was significant $(p<0.01)$ is presented in Table 7 and was found significantly higher in Arun-4 (19.26\%) and Arun-2 (15.72\%) while lowest in Rampur Hybrid-10 (10.39\%).

\section{Shelling percentage}

Shelling percentage of different maize varieties are presented in Table 7 and was significant $(\mathrm{p}<0.05)$. Shelling percentage was highest $(63.08 \%)$ in Rajkumar which was at par with Rampur composite (55.48\%). Lowest shelling percentage (51.62\%) was recorded in Arun-2. 
Table 7. Yield and yield attributing character of different maize varieties at Baitadi, 2020

\begin{tabular}{lllllll}
\hline \multicolumn{1}{c}{ Treatments } & $\begin{array}{c}\text { Sterility } \\
\%\end{array}$ & Shelling\% & TGW & $\begin{array}{c}\text { Grain } \\
\text { yield }(\mathrm{t} \mathrm{ha} \\
1^{-}\end{array}$ & $\begin{array}{c}\text { Biological } \\
\text { yield } \\
\left(\mathrm{tha}^{-1}\right)\end{array}$ & $\begin{array}{c}\text { Harvest } \\
\text { index }(\%)\end{array}$ \\
\hline Arun-2 & $15.72^{\mathrm{b}}$ & $51.62^{\mathrm{b}}$ & $195^{\mathrm{ab}}$ & $3.99^{\mathrm{b}}$ & $21.8^{\mathrm{a}}$ & $18.12^{\mathrm{b}}$ \\
Arun-4 & $19.56^{\mathrm{b}}$ & $52.01^{\mathrm{b}}$ & $152.5^{\mathrm{b}}$ & $2.33^{\mathrm{c}}$ & $13.99^{\mathrm{b}}$ & $16.85^{\mathrm{b}}$ \\
Rampur composite & $11.30^{\mathrm{a}}$ & $55.48^{\mathrm{ab}}$ & $212.5^{\mathrm{a}}$ & $4.58^{\mathrm{ab}}$ & $19.38^{\mathrm{a}}$ & $23.84^{\mathrm{a}}$ \\
Rajkumar & $11.30^{\mathrm{a}}$ & $63.08^{\mathrm{a}}$ & $212.5^{\mathrm{a}}$ & $5.32^{\mathrm{a}}$ & $20.11^{\mathrm{a}}$ & $26.52^{\mathrm{a}}$ \\
Rampur Hybrid-10 & $10.39^{\mathrm{a}}$ & $53.13^{\mathrm{b}}$ & $231.25^{\mathrm{a}}$ & $4.75^{\mathrm{ab}}$ & $20.8^{\mathrm{a}}$ & $22.90^{\mathrm{a}}$ \\
\hline LSD (0.05) & 3.99 & 7.95 & 46.46 & 1.08 & 4.05 & 4.50 \\
SEm $( \pm)$ & 1.74 & 2.11 & 13.36 & 0.51 & 1.37 & 1.81 \\
CV, \% & 19.01 & 9.37 & 15.02 & 16.69 & 13.67 & 13.51 \\
P-value & $0.001^{* *}$ & $0.05^{*}$ & $0.03^{*}$ & $0.0006^{* * *}$ & $0.001^{* *}$ & $0.003^{* *}$ \\
\hline Grand Mean & 13.65 & 55.06 & 200.75 & 4.19 & 19.23 & 21.65 \\
\hline
\end{tabular}

Note: The common letter(s) within the column indicate non-significant difference based on Duncan Multiple Range Test (DMRT)

\section{Thousand grain weight}

Thousand grain weights ( $\mathrm{g}$ ) of different maize varieties are presented in Table 7 and was significant $(\mathrm{p}<0.05)$. The higher thousand grain weight was observed in Rampur Hybrid-10 (231.25 g), Rajkumar (212.5 g) and Rampur composite (212.5 g) and the lower thousand grain weight obtained in Arun-4 (152.5 g).

\section{Varietal effects on Yield}

\section{Grain yield}

The mean data of research finding indicated that significantly $(\mathrm{p}<0.001)$ highest grain yield $\left(5.32 \mathrm{t} \mathrm{ha}^{-1}\right)$ obtained in Rajkumar which was at equivalence with Rampur Hybrid-10 (4.75 $\mathrm{Mt} \mathrm{ha}^{-1}$ ) and Rampur composite (4.58 $\left.\mathrm{t} \mathrm{ha}^{-1}\right)$. The result is in agreement with (Devkota et al., 2020) and lowest grain yield $\left(2.33 \mathrm{t} \mathrm{ha}^{-1}\right)$ obtained in Arun-4. Grain and biological yield were lower in Arun-4 variety. Raut, et al., (2017) reported that there were highly significant differences for grain yield and yield attributing traits among genotypes which strongly support the present finding. Hybrid maize produced higher yield than open pollinated variety (Ghimire et al., 2016).

Maize as being subtropical crop is sensitive to low temperature at early growth stages and the performance of hybrid maize in terms of growth attributes was poor at low temperature in field experiment (Ahmad et al. 2014). Further, in spring crop temperature becomes high at reproductive stages which are not desirable and 
exposure to such temperature promotes pollen desiccation resulting in yield losses while in early stages seedlings are weakened and grain yield is reduced (Bano et al., 2015). Due to the low temperature from sowing to the long vegetative growth stages of different maize varieties resulted in less dry matter and less photosynthate formation thus decrease in yield of varieties (Amgain, 2011).

\section{Biological yield}

Biological yield $\left(\mathrm{t} \mathrm{ha}^{-1}\right)$ of different maize varieties is presented in Table 7 and was significant $(\mathrm{p}<0.01)$. The highest biological yield produced by Arun-2 $\left(21.80 \mathrm{t} \mathrm{ha}^{-1}\right)$ and Rampur Hybrid-10 (20.86 $\left.\mathrm{t} \mathrm{ha}^{-1}\right)$ and the lowest biological yield (13.99 $\left.\mathrm{t} \mathrm{ha}^{-1}\right)$ produced by Arun- 4 .

\section{Harvest index}

Harvest index of different maize varieties are presented in Table 7 and was significant with harvest index $(\mathrm{p}<0.01)$. The highest harvest index was found in Rajkumar $(26.52 \%)$ and Rampur composite $(23.84 \%)$ and lowest harvest index was found in Arun-4 (16.85\%).

Among abiotic stresses, low temperature is a sever threat for spring maize in early growth stages which resulted in reduced crop growth rate and thus the growth duration is prolonged (Bano et al., 2015). The occurrence of extreme environmental condition during the growing period of maize thereby, affects growth duration, plant size, dry matter accumulations, assimilation reserves and partitioning to grains (Bello et al., 2014).

\section{Relationship between yield attributes and grain yield}

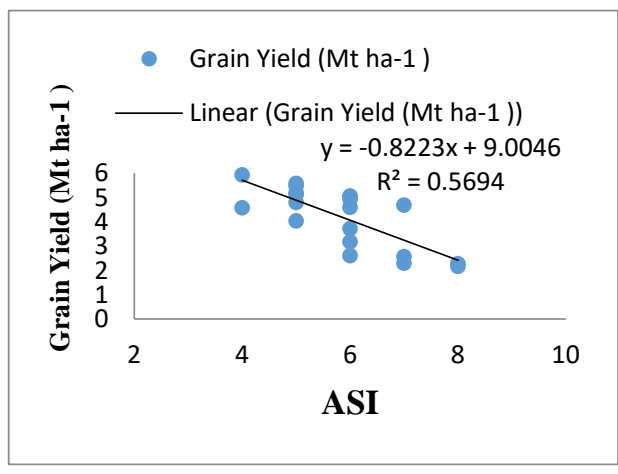

Figure 2. Relation between grain yield and ASI

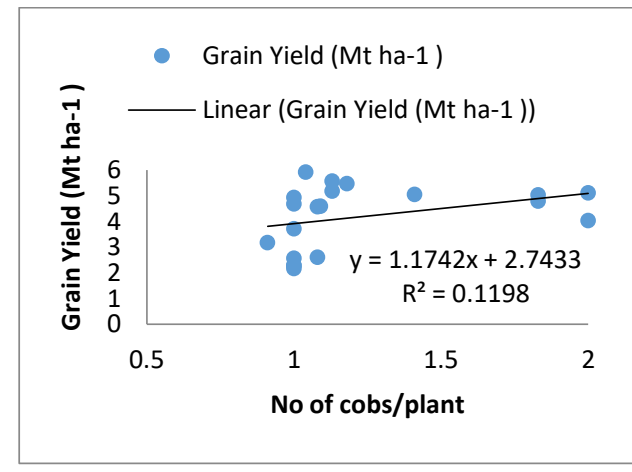

Figure 3. Relation between grain yield and cobs/plant 


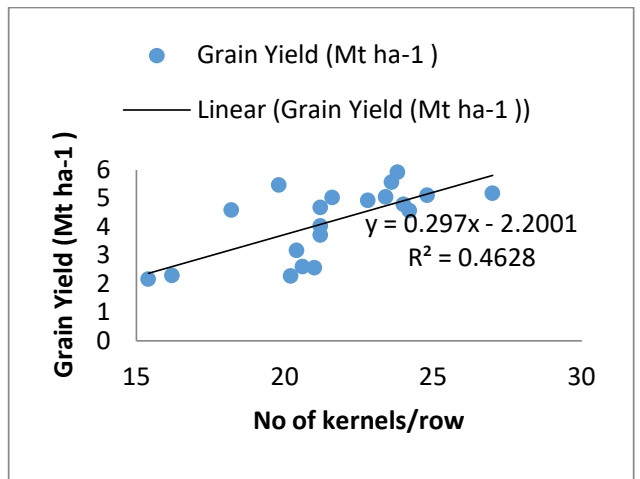

Figure 4. Relation between grain yield and kernels/cob

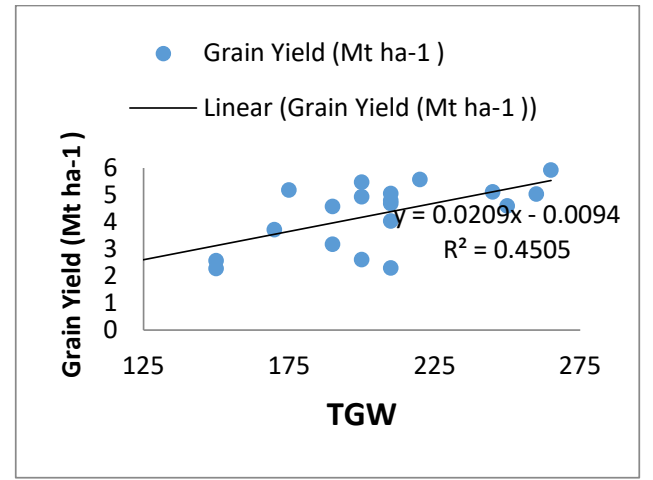

Figure 5. Relation between grain yield and TGW

Fig. 2 indicates the equation of linear regression analysis between grain yield and ASI among all the varieties grown. It represents negative correlation of ASI with the total grain yield of different maize varieties. It explained about $56.9 \%$ variations in grain yield is accounted by ASI of maize varieties.

The equation of linear regression analysis (Fig. 3, 4 and 5) showed that trend of grain yield with no of cobs/plant, no of kernels/row and TGW respectively. It showed that all the attributes were positively correlated with yield of maize varieties. Regression analysis had shown number of ASI, kernels/row and TGW have important role in variation in yield contributed about $56.9 \%, 46.3 \%$, and $45.05 \%$ respectively. Similarly, number of cobs/plants had attributed $12 \%$ variation in grain yield respectively.

\section{CONCLUSION}

Among five different maize varieties cultivated in spring season at Baitadi, Rajkumar $\left(5.32 \mathrm{t} \mathrm{ha}^{-1}\right)$ has higher yield followed by Rampur Hybrid-10 (4.75 $\left.\mathrm{t} \mathrm{ha}^{-1}\right)$ among hybrids and Rampur composite $\left(4.58 \mathrm{t} \mathrm{ha}^{-1}\right)$ has the highest yield among open pollinated varieties. Thus, this research suggested the farmers of Baitadi district to cultivate Rajkumar variety as hybrid and Rampur composite as open pollinated in spring season to increase the productivity of maize.

\section{REFERENCES}

Ahmad, I., Maqsood, S., Basra, A. and Wahid, A. (2014). Exogenous application of ascorbic acid, salicylic acid and hydrogen peroxide improves the productivity of hybrid maize at low temperature stress. International Journal of Agriculture and Biology, 16: 25-830.

AICC. (2021). Krishi and Livestock Diary. Hariharbhawan, Lalitpur: Ministry of Agriculture and Livestock Development, Agriculture Information and Communication Center. 
Amgain, L. (2011). Accumulated heat unit and phenology of diverse maize varieties as affected by planting dates under Rampur condition, Nepal. Agronomy Journal of Nepal, 2: 111-120.

Bano, S., Aslam, M., Saleem, M., Basra, S. and Aziz, K. (2015). Evaluation of maize accessions under low temperature stress at early growth stages. The Journal of Animal \& Plant Sciences, 25(2): 392-400.

Bello, O.B., Olawuyi, O.J., Abdulmaliq, S.Y., Ige, S.A., Mahamood, J., Azeez, M.A. and Afolabi, M.S. (2014). Yield and disease reactions of quality protein maize varieties in the Southern Guinea Savanna Agro-Ecology of Nigeria. Sarhad Journal of Agriculture, 30(1): 53-66.

Biru, A. (1976). Agronomy research manual. Part II. In Information for special trial for particular crops.

Devkota, S., Karn, R., Jha, R.K., Marasini, D. and Sah, S.K. (2020). Evaluation of open pollinated and hybrid maize varieties in Dhading district of Nepal. Journal of Agriculture and Natural Resources, 3(1): 160-169.

Elmore, R. (2012). Influence of Soil Temperature on Corn Germination and Growth. Iowa State University of Science and Technology.

Ghimire, S., Sherchan, D., Andersen, P., Pokhrel, C., Ghimire, S. and Khanal, D. (2016). Effect of variety and practice of cultivation on yield of spring maize in terai of Nepal. Agrotechnology, 5(2): 1-6.

JICA. (2016). Maize Farming Techniques Manual. Sindhupalchowk, Chautara: District Agriculture Development Office, Ministry of Agriculture Development, Government of Nepal.

Karki, T., Kc, G., Shrestha, J. and Jadav, J. (2015). Tillage and planting density affect the performance of maize hybrids in chitwan, Nepal. Journal of Maize Research and Development, 1(1): 10-20.

Kc, G., Karki, T., Shrestha, J. and Achhami, B. (2015). Status and prospects of maize research in Nepal. Journal of Maize Research and Development, 1(1): 1-9.

Khanal, P., Karn, R., Budhathoki Chhetri, P., Karki, S., and Sah, S. K. (2019). response of maize varieties to sowing dates in inner Terai region, Dang, Nepal. Malaysian Journal of Halal Research Journal, 2(2): 27-31.

Kunwar, C.B. and Shrestha, J. (2014). Evaluating Performance of Maize hybrids in Terai Region of Nepal. World Journal of Agricultural Research, 2(1): 22-25.

Lambert, R.J., Mansfield, B.D. and Mumm, R.H. (2014). Effect of leaf area on maize productivity. Maydica, 59(1): 58-64.

Lamichhane, J., Timsina, K.P., RanaBhat, D.B. and Adhikari, S. (2015). Technology adoption analysis of improved maize technology in western hills of Nepal. Journal of Maize Research and Development, (1):146-152.

MOALD. (2017). Statistical Information on Nepalese Agriculture, 2016/17. Singha Durbar, Kathmandu, Nepal: Ministry of Agricultural Development, Monitoring, Evaluation and Stastistics Division, Agri Stastistics Section.

NMRP. (2015). Characteristics of Maize Varieties Developed and Released in Nepal (19662015). Rampur, Chitwan: Government of Nepal, Nepal Agriculture Research Council. 
Pandey, K., Shrestha, B., Naharki, K. and Kunwar, C.B. (2019). Assessment of maize production and adoption of improved maize seeds in Tanahun district of Nepal. International Journal of Applied Sciences and Biotechnology, 7(2): 279-288.

PMAMP. (2019). Annual Progress and Technical Manual, 2018/19. Baitadi, Nepal: Ministry of Agriculture and Livestock, Government of Nepal.

Pokhrel, T. (2013). Impact of maize varieties disseminated in Chitwan, Nepal. Economic Journal of Nepal, 42(6): 45-53.

Prasai, H.K., Kushwaha, U.K., Joshi, B.P. and Shrestha, J. (2015). Performance evaluation of early maize genotypes in Far western hills of Nepal. Journal of Maize Research and Development, 1(1): 106-111.

Raut, S.K., Ghimire, S.K., Kharel, R., Kuwar, C. B., Sapkota, M. and Kushwaha, U.K. (2017). study of yield and yield attributing traits of Maize American. Journal of Food Science and Health, 3(6): 123-129.

Sabiel, S.A., Abdelmula, A.A., Bashir, E., Sun, Y., Baloch, S.K., Yang, Y. and Bashir, W. (2014). Genetic variation of plant height and stem diameter traits in maize (Zea mays L.) under drought stress at different growth stages. Journal of Natural Sciences Research, 4(23): 116-122.

SQCC. (2013). National Seed Vision 2013-2015. Hariharbhawan, Lalitpur, Nepal: Government of Nepal, Ministry of Agricultural Development, National Seed Board Seed Quality Control Centre.

Swanson, S. and Wilhelm, W. (1996). Planting date and residue rate effects on growth, partitioning, and yield of corn. Agronomy Journal, 88(2): 205-210.

World Weather Online. (2020). Retrieved from World Weather Online.

Zhang, B., Xu, D., Liu, Y., Li, F., Cai, J. and Du, L. (2016). L. Multi-scale evapotranspiration of summer maize and the controlling meteorological factors in north China. Agricultural and Forest Meteorology, 216: 1-12. 